\title{
Dinamika Pelaksanaan Kebijakan Program Pelayanan Penyandang Masalah Kesejahteraan Sosial Anak Jalanan
}

\begin{abstract}
Vita Rachmawati ${ }^{1}$, Dodi Faedlulloh ${ }^{2 *}$
${ }^{1}$ Program Studi Ilmu Administrasi Publik, Universitas 17 Agustus 1945 Jakarta, 14350, Jakarta Utara-Indonesia

${ }^{2}$ Jurusan Ilmu Administrasi Negara, Universitas Lampung, 35141, Bandar Lampung-Indonesia

\begin{tabular}{l}
\hline \hline Info Artikel \\
\hline Dikirim: Okt 26, 2020 \\
Diterima: Jan 18, 2021 \\
Dipublikasi: Jan 31, 2021 \\
\hline Kata Kunci: \\
Anak Jalanan; \\
Kebijakan; \\
Kesejahteraan; \\
\hline
\end{tabular}

Koresponden:

Dodi Faedlulloh

Jurusan Ilmu Administrasi

Negara

Universitas Lampung

\section{Email:}

dodi.faedlulloh@fisip.unil

ABSTRAK

Abstract This research is motivated by the relatively high number of people with social welfare problems for street children in North Jakarta compared to other cities in the DKI Jakarta Province. Therefore, serious efforts from the government are needed to overcome this problem. This study discusses the dynamics of the implementation of the policy on the service program for people with social welfare problems for street children in North Jakarta. This study uses a qualitative method. To select informants, researchers used purposive sampling. To measure the validity of the study, the researcher used source triangulation by comparing data from observations and interviews, conditions with people's perspectives, and interviews with document content. The results showed that the communication process in the implementation of handling street children has not been implemented properly. This occurs because there are conditions in the delivery of information that are still ineffective. Furthermore, resources related to staff, information, authority, and facilities also each have shortcomings so that they lack effectiveness in terms of policy resources. In the context of disposition, it shows that policy implementers have not yet optimal responses in implementing policies on handling street children in North Jakarta. Meanwhile, from the bureaucratic structure, the implementing institution has its own SOP. The implementation of policies on handling street children in North Jakarta has not experienced fragmentation.
\end{abstract} a.ac.id

\section{Sitasi Cantuman:}

Rachmawati, V., \& Faedlulloh, D. (2021). Dinamika Pelaksanaan Kebijakan Program Pelayanan Penyandang Masalah Kesejahteraan Sosial Anak Jalanan. Journal of Political Issues. 2(2); 67-78. https://doi.org/10.33019/jpi.v $2 \mathrm{i} 2.38$

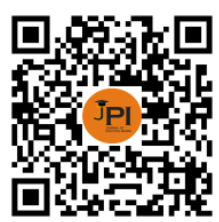

DOI:

https://doi.org/10.33019/jpi.v $2 \mathrm{i} 2.38$

Lisensi:

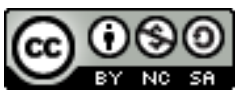

Attribution-NonCommercialShareAlike 4.0 International (CC- BY-NC-SA 4.0)

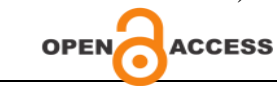

Abstrak Penelitian ini dilatarbelakangi oleh cukup tingginya jumlah penyandang masalah kesejahteraan sosial anak jalanan di Jakarta Utara dibandingkan dengan Kota lain di wilayah Provinsi DKI Jakarta. Oleh karenanya perlu upaya serius dari pemerintah untuk mengatasi permasalahan ini. Penelitian ini membahas tentang dinamika pelaksanaan kebijakan program pelayanan penyandang masalah kesejahteraan sosial anak jalanan di Jakarta Utara. Penelitian ini menggunakan metode kualitatif. Untuk memilih informan peneliti menggunakan purposive sampling. Untuk mengukur validitas penelitian, peneliti menggunakan triangulasi sumber dengan membandingkan data hasil pengamatan dan wawancara, keadaan dengan perspektif orang, dan hasil wawancara dengan isi dokumen. Hasil penelitian menunjukkan proses komunikasi dalam pelaksanaan penanganan anak jalanan belum terlaksana dengan baik. Hal ini terjadi karena ada kondisi penyampaian informasi yang masih kurang efektif. Selanjutnya sumberdaya yang berkaitan dengan staff, information, authority, dan facilities juga masing-masing memiliki kekurangan sehingga kekurangan efektivitas dalam hal sumberdaya kebijakan. Dalam konteks disposisi menunjukkan bahwa para pelaksana kebijakan memiliki respon yang belum optimal dalam menjalankan kebijakan penanganan anak jalanan di Jakarta Utara. Sedangkan dari stuktur birokrasi, institusi pelaksana telah memiliki SOP tersendiri. Pelaksanaan kebijakan penanganan anak jalanan di Jakarta Utara tidak mengalami fragmentasi.

Tentang:

Vita Rachmawati, Penulis menyelesaikan studi S1 di Program Studi IlmuAdministrasi Publik, Universitas 17 Agustus 1945 Jakarta.

Dodi Faedlulloh, Penulis menyelesaikan studi S2 di Magister Ilmu Administrasi Universitas Jenderal Soedirman tahun 2014. Saat ini penulis bekerja sebagai dosen di Jurusan Ilmu Administrasi Negara, Universitas Lampung. 


\section{PENDAHULUAN}

Salah satu permasalahan urban yang sering ditemui adalah masalah kesejahteraan sosial anak jalanan. Seringkali fenomena anak jalanan di sudut-sudut kota menjadi pemandangan seharihari yang lazim ditemui masyarakat. Tidak ada waktu belajar, masa kecil mereka terserap oleh kerja-kerja jalanan untuk sekadar bertahan hidup. Terminologi yang digunakan negara untuk "mendefiniskan" permasalahan ini sebagai Penyandang Masalah Kesejahteraan Sosial (PMKS). Walaupun terkini, ada wacana dari Kementerian Sosial yang akan mengganti sebutan bagi penerima bantuan sosial dari PMKS menjadi Pemerlu Pelayanan Kesejahteraan Sosial (PPKS). Namun secara paradigmatik, kita perlu memberikan kontribusi kritik apakah titik koordinat pandangan negara dalam melihat permasalahan ini bergeser pula atau tidak. Hal ini layak untuk didiskusikan lebih mendalam.

Penyandang Masalah Kesejahteraan Sosial (PMKS) merupakan seseorang, keluarga atau kelompok masyarakat yang karena suatu hambatan, kesulitan atau gangguan tidak dapat melaksanakan fungsi sosialnya, sehingga tidak dapat terpenuhi kebutuhan hidupnya baik jasmani, rohani dan sosial secara memadai dan wajar (Suleman et al., 2019). Hambatan, kesulitan dan gangguan tersebut dapat berupa kemiskinan, keterlantaran, kecacatan, ketunaan sosial, keterbelakangan, keterasingan atau keterpencilan dan perubahan lingkungan (secara mendadak) yang kurang mendukung, seperti terjadinya bencana. Dari dua puluh enam jenis penyandang masalah kesejateraan sosial, meliputi Anak Balita Telantar, Anak Telantar, Anak Nakal, Wanita Rawan Sosial Ekonomi, Korban Tindak Kekerasan, Lanjut Usia Telantar, Penyandang Cacat, Tuna Susila, Pengemis, Gelandangan, Korban Penyalahgunaan NAPZA, Keluarga Fakir Miskin dll, salah satunya ialah anak jalanan yang telah disinggung di awal.

Keberadaan anak jalanan dilatarbelakangi oleh kemiskinan, penyimpangan kepribadian, dan faktor luar dari anak jalanan tersebut. Faktanya sebagian besar anak jalanan memang berasal dari keluarga miskin. Hal inilah yang merupakan pemicu utama anak melakukan kegiatan di jalanan. Kondisi tersebut terjadi akibat tidak terpenuhi kebutuhan hidupnya (Astri, 2014). Secara Psikologis, anak jalanan adalah anak -anak yang pada suatu taraf tertentu belum memiliki cukup mental dan emosional yang kuat, Sementara mereka harus bergelut dengan dunia jalanan yang keras dan cenderung berpengaruh negatif bagi perkembangan dan pembentukan kepribadiannya (Suyanto, 2013).

Pada umumnya problem anak jalanan banyak berada di kota-kota, keberadaan mereka pun juga tersebar hampir di seluruh dunia terutama negara berkembang seperti di Indonesia (Mambang \& Wahyudi, 2016). Fenomena anak jalanan berhubungan dengan masalah-masalah lain, baik secara internal maupun eksternal, seperti ekonomi, psikologi, sosial, budaya, lingkungan, pendidikan, agama, dan keluarga. Mereka korban dari kondisi yang dialami individu, baik internal, eksternal maupun kombinasi keduanya. Munculnya anak jalanan, tidak bisa dilihat dari faktor ekonomi saja, tetapi banyak faktor yang menjadi pemicu, seperti kemiskinan, perhatian keluarga, kenakalan remaja, pola asuh yang salah (Khoirunnisa et al., 2020).

Masalah sosial anak jalanan merupakan fenomena sosial yang tidak bisa dihindari keberadaannya dalam kehidupan masyarakat, terutama yang berada di daerah perkotaan. Salah satu faktor yang dominan mempengaruhi perkembangan masalah ini adalah kemiskinan. Masalah kemiskinan di Indonesia berdampak negatif terhadap meningkatnya arus urbanisasi dari daerah pedesaan ke kota-kota besar. Sehingga lapangan pekerjaan yang tersedia, serta terbatasnya pengetahuan dan keterampilan menyebabkan mereka banyak yang mencari nafkah untuk mempertahankan hidup dengan terpaksa menjadi anak jalanan. 
Tabel 1 Data Anak Jalanan di Suku Dinas Sosial di Wilayah Jakarta Tahun 2015 s/d Tahun 2016

\begin{tabular}{ccccc}
\hline \multirow{2}{*}{ No } & Anak Jalanan di Wilayah & $\mathbf{2 0 1 5}$ & 2016 & Jumlah \\
\cline { 3 - 5 } 1. & Jakarta Utara & 551 Jiwa & 405 Jiwa & 956 Jiwa \\
\hline 2. & Jakarta Selatan & 75 Jiwa & 215 Jiwa & 290 Jiwa \\
\hline 3 & Jakarta Pusat & 108 Jiwa & 150 Jiwa & 213 Jiwa \\
\hline 4. & Jakarta Barat & 263 Jiwa & 275 Jiwa & 538 Jiwa \\
\hline 5 & Jakarta Timur & 260 Jiwa & 285 Jiwa & 545 Jiwa \\
\hline & Total & 1257 Jiwa & 1330 Jiwa & 2542 Jiwa \\
\hline & \multicolumn{2}{c}{ Sumber: Suku Dinas Sosial Jakarta Utara Tahun }
\end{tabular}

Berdasarkan tabel di atas, jumlah penyandang masalah kesejahteraan sosial anak jalanan di Suku Dinas Sosial paling banyak di Wilayah Jakarta Utara dengan jumlah 956 jiwa. Dalam hal ini, untuk meminimalisir jumlah penyandang masalah kesejahteraan sosial anak jalanan, Pemerintah telah kebijakan penanganan anak jalanan melalui penjangkauan dan pemulangan penyandang masalah kesejahteraan sosial ke daerah asal yang diatur dalam Peraturan Daerah No. 8 Tahun 2007 tentang ketertiban umum bebas penyandang masalah kesejahteraan sosial jalanan.

Anak jalanan merupakan anak berusia 5-18 tahun baik laki-laki maupun perempuan yang menghabiskan sebagian besar waktunya di jalan, memiliki komunikasi yang minimal atau sama sekali tidak pernah berkomunikasi dengan keluarga dan kurang pengawasan, perlindungan dan bimbingan sehingga rawan terkena gangguan kesehatan dan psikologi (UNICEF) (Azmiyati, 2014). Peran pemerintah dalam menangani masalah sosial anak jalanan sangat penting, sebagaimana yang diamanatkan dalam Pasal 27 Ayat (2) dan Pasal 34 Ayat (1) Undang-Undang Dasar Negara Republik Indonesia Tahun 1945 Amandemen keempat. Pasal 27 Ayat (2) Undang-Undang Dasar 1945 Amandemen keempat berbunyi "Tiap-tiap warga negara berhak atas pekerjaan dan penghidupan yang layak bagi kemanusiaan". Pasal ini memberikan pengertian bahwa pemerintah berkewajiban untuk memberantas pengangguran dan harus mengusahakan supaya setiap warga negara dapat memperoleh pekerjaandengan upah yang layak untuk hidup. Salah satunya dimanifestasikan dengan cara merumuskan kebijakan program pelayanan Penyandang Masalah Kesejahteraan Sosial (PMKS) untuk menanggulangi masalah anak jalanan tersebut. Karena semua masalah yang timbul merupakan agenda tetap pemerintah untuk mendapatkan penyelesaiannya dengan menuangkannya melalui kebijakan-kebijakan yang dibuat oleh pemerintah.

Kebijakan Pemerintah Daerah Kota Jakarta Utara untuk menangani anak jalanan sendiri juga dibuat berdasarkan pada peraturan perundang-undangaan yang telah ada sebelumnya yaitu Peraturan perundang-undangan yang berkaitan dengan kesejahteraan anak jalanan antara lain: UU No. 11 Tahun 2009 tentang Kesejahteraan Sosial, Peraturan Pemerintah No. 31 Tahun 1980 tentang Penanggulangan anak jalanan anak terlantar, Peraturan Daerah No. 8 tahun 2007 tentang ketertiban umum bebas penyandang masalah kesejahteraan sosial Jalanan, Kepmensos No. 30/HUK/1996 tentang rehabilitasi anak jalanan di dalam panti sosial, Peraturan Gubernur No. 19 tahun 2014 tentang satuan pelayanan pengawasan dan pengendalian sosial penyandang masalah kesejahteraan sosial jalanan.

Beberapa peraturan perundangan tersebut di atas merupakan kebijakan publik atau yang sering disebut kebijakan negara, karena kebijakan itu dibuat negara. Bila dikaitkan dengan tujuan kebijakan, maka yang hendak dicapai adalah untuk mewujudkan kehidupan yang sejahtera untuk kaum marjinal di Indonesia. Dalam bentuknya yang positif, kebijakan publik didasarkan pada undang-undang dan bersifat otoritatif. Sifat kebijakan bisa diperinci menjadi beberapa kategori yakni tuntutan-tuntutan kebijakan (policy demands), keputusankeputusan kebijakan (policy decision), pernyataan-pernyataan kebijakan (policy statements), 
hasil-hasil kebijakan (policy outputs), dan dampak-dampak kebijakan (policy outcomes)(Winarno, 2008).

Kebijakan tidak berada dalam ruang vakum, oleh karenanya kebijakan selalu berkelindan dengan kondisi riil masyarakat. Kebijakan tidak hanya dirumuskan lalu dibuat dalam suatu bentuk positif seperti undang-undang dan kemudian didiamkan, tetapi sebuah kebijakan publik harus dilaksanakan atau di implementasikan melalui program-program agar mempunyai dampak kepada masyarakat. Tetapi pada kenyataanya tidak semua program pelayanan pada Suku Dinas Sosial berjalan sesuai dengan apa yang diharapkan dan direncanakan. Dalam pelaksanaan otonomi daerah yang mana pemerintah daerah diberikan wewenang untuk mengurus rumah tangganya sendiri. Maka dengan adanya indikasi tersebut Pemerintah Daerah Kota Jakarta Utara melalui Suku Dinas Sosial yang menagani masalah sosial, khususnya anak jalanan akan sangat berperan sekali dalam mengatasi masalah anak jalanan yang semakin lama semakin rumit.

Dalam menjalankan program pelayanan penyandang masalah kesejahteraan sosial anak, Suku Dinas Sosial Jakarta Utara bekerja sama dengan beberapa Panti Sosial yaitu Panti Sosial Bina Bangun Daya 2 Cipayung Jakarta Timur dan Panti Sosial Bina Bangun Daya 1 Kedoya Jakarta Barat yang khusus menagani masalah anak jalanan. Bagi PMKS anak jalanan yang berada di panti tersebut akan diberikan bekal pemberdayaan masyarakat seperti pelatihan dan pembinaan serta diajarkan berbagai keterampilan dan kerajinan tangan sesuai dengan minat dan bakatnya masing-masing, sehingga pada saat PMKS anak jalanan ini keluar dari panti mereka mempunyai kemampuan dan keahlian dalam menghasilkan sebuah karya seni berupa kerajinan tangan yang memiliki nilai jual ekonomis yang tinggi untuk meningkatkan pekonomian mereka. Diharapkan nantinya dengan program program pelayanan yang diberikan oleh Suku Dinas Sosial Jakarta Utara tersebut dapat memberikan salah solusi alternatif untuk mengurangi jumlah anak jalanan dan mengembalikan mereka untuk hidup normal dan layak di dalam masyarakat.

Dari latar belakang di atas, penulis tertarik untuk meneliti tentang dinamikan pelaksanaan program pelayanan penyandang masalah kesejahteraan sosial anak di DKI Jakarta. Adapun tujuan diadakan penelitian ini adalah untuk mengetahui dinamika proses pelaksanaan Kebijakan Program Pelayanan Penyandang Masalah Kesejahteraan Sosial (PMKS) Anak Jalanan pada Suku Dinas Sosial di Jakarta Utara.

\section{METODE PENELITIAN}

Secara sistematis, penelitian ini menggunakan metode kualitatif. Metode kualitatif merupakan prosedur pengumpulan data yang menghasilkan data deskriptif berupa kata-kata tertulis atau lisan dari orang-orang dan perilaku yang diamati (Moleong, 2004). Sedangkan untuk memilih informan peneliti menggunakan purposive sampling yaitu Kepala Seksi Rehabilitasi dan pemberdayaan sosial, Staf Rehabilitasi Sosial, Petugas Pengawasan dan Pengendalian Sosial (P3S), masyarakat, dan anak jalanan.

Lokasi penelitian ini dilakukan di Kantor Suku Dinas Sosial Jakarta Utara. Adapun Suku Dinas Sosial Jakarta Utara memiliki beberapa anak asuhan. Semua anak jalanan tersebut dititipkan di Panti Sosial Bina Bangun Daya 2 Cipayung Jakarta Timur dan Panti Sosial Bina Bangun Daya 1 Kedoya Jakarta Barat. Untuk mengukur validitas penelitian, peneliti menggunakan triangulasi sumber dengan membandingkan data hasil pengamatan dan wawancara, keadaan dengan perspektif orang, dan hasil wawancara dengan isi dokumen (Moleong, 2004). Untuk mendukung hasil dari penelitian lapangan, peneliti juga menggunakan pendekatan studi kepustakaan dengan penelitian berbasis data sekunder. Studi kepustakaan merupakan teknik pengumpulan data dengan mengadakan studi penelaahan terhadap buku-buku, literatur-literatur, catatan-catatan, laporan-laporan yang ada kaitannya dengan masalah yang hendak dipecahkan (Nazir, 2009). 


\section{HASIL PENELITIAN DAN PEMBAHASAN}

Hidup menjadi anak jalanan memang bukan merupakan pilihan yang menyenangkan, karena mereka berada dalam kondisi yang tidak bermasa depan jelas, dan keberadaan mereka tidak jarang menjadi "masalah" bagi banyak pihak, keluarga, masyarakat dan negara. Namun, perhatian terhadap nasib anak jalanan tampaknya belum begitu besar dan solutif. Padahal mereka adalah bagian dari warga negara yang perlu dijamin hak-haknya, sehingga tumbuhkembang menjadi manusia dewasa yang bermanfaat, beradab dan bermasa depan cerah. Menurut UUD 1945, "anak terlantar itu dipelihara oleh negara." Artinya pemerintah mempunyai tanggung jawab terhadap pemeliharaan dan pembinaan anak-anak terlantar, termasuk anak jalanan.

Berdasarkan Peraturan Daerah No. 8 tahun 2007 tentang ketertiban umum Suku Dinas Sosial Kota Administrasi Jakarta Utara mempunyai tugas yang di dalamnya mencakup tentang penertiban, pembinaan dan pelayanan sosial, pemulangan PMKS, khususnya anak jalanan ke daerah asal. Peraturan Daerah yang dibuat dan dikeluarkan oleh Pemerintah Kota Jakarta Utara itu merupakan kebijakan publik. Dalam riset ini, penulis menggunakan dan mengadaptasi teori kebijakan yang dikemukakan oleh Edward III (1980) dalam melihat pelaksanaan Program Pelayanan Penyandang Masalah Kesejahteraan Sosial Anak Jalanan di Jakarta Utara. Setidaknya ada empat faktor yang mempengaruhi implementsi kebijakan yaitu faktor komunikasi, sumber daya, disposisi dan struktur birokrasi. Menilik pengaruh keempat faktor ini pada implementasi kebijakan program pelayanan penyandang masalah kesejahteraan sosial anak jalanan adalah sebagai berikut:

\section{Komunikasi}

Komunikasi merupakan penyampaian informasi kebijakan dari pembuat kebijakan kepada pelaksana kebijakan dan diefektifkan lagi dengan disampaikan juga kepada kelompok sasaran kebijakan serta pihak lain yang berkepentingan. Indikator dalam komunikasi yaitu proses transmisi/penyaluran komunikasi, kejelasan komunikasi dan konsistensi (Nurahmah, 2020). Aspek dari komunikasi ini berupa keputusan-keputusan kebijakan penanganan anak jalanan, petunjuk pelaksanaan, perintah dan lain-lain. Sehingga komunikasi yang terjadi berupa komunikasi internal dan komunikasi eksternal.Komunikasi internal terjadi antar pejabat Dinas Sosial yaitu pejabat struktural Dinas Sosial Provinsi dan Pejabat Unit

Pelaksana Teknis (UPT) berupa panti-panti, rumah singgah. Komunikasi internal ini disampaikan dalam bentuk formal seperti rapat dan non-formal seperti perintah langsung atasan terhadap bawahan. Komunikasi eksternal terjadi di antara pejabat UPT dengan anak jalanan. Dalam komunikasi ini bertujuan agar mereka mengetahui keadaan lapangan yang sesungguhnya, apa yang harus dipersiapkan dan dilaksanakan guna tujuan kebijakan penanganan anak jalanan agar dapat tercapai dan terwujud. Dalam komunikasi ini bertujuan agar mereka mengetahui keadaan lapangan yang sesungguhnya, apa yang harus dipersiapkan dan dilaksanakan guna tujuan kebijakan penanganan anak jalanan agar dapat tercapai dan terwujud. Arus komunikasi yang terjadi dalam implementasi kebijakan penanganan anak jalanan dapat dilihat sebagai berikut: 


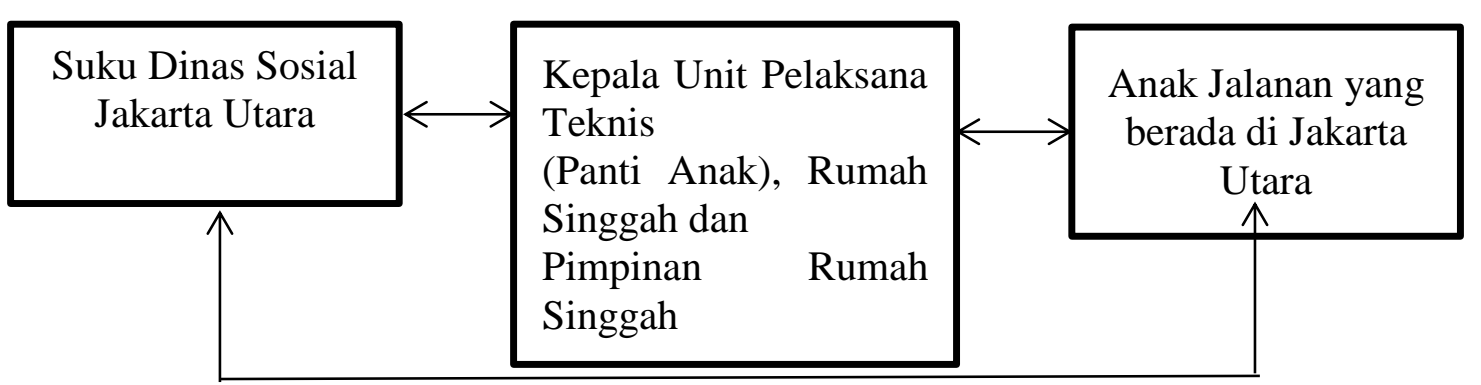

Gambar 1 Arus Komunikasi

Transmisi komunikasi dalam proses pelaksanaan kebijakan telah berjalan dengan baik. Hal ini ditunjukkan dengan birokrasi yang relatif pendek dalam penanganan anak jalanan. Sedangkan dalam konteks kejelasan komunikasi, temuan di lapangan menunjukkan kejelasan informasi yang dilakukan oleh pemerintah masih kurang. Hal ini ditandai dengan fakta sosialisasi yang belum jelas dan masih banyak anak jalanan yang belum mengetahui mengenai kebijakan penanganan anak jalanan tersebut.

Ketidakjelasakan komunikasi ini terjadi dikarenakan masih banyak masyarakat dan anak jalanan tentang program yang sedang diselenggarakan oleh pemerintah terutama dalam penanganan anak jalanan. Adapun mereka yang tahu itu hanya sebatas "sambil lalu" karena mendapat informasi tidak sengaja melalui pamflet atau dari aplikasi qlue. Oleh karena itu, titik tekannya masih permasalahan mendasar, yakni masih perlu adanya sosialisasi yang lebih giat agar kebijakan dapat tersampaikan kepada masyarakat maupun kepada anak jalanan (Diolah hasil wawancara dengan Kepala Seksi Rehabilitasi Sosial tanggal 25 April 2017).

Tingginya mobilitas dari para anak jalanan yang tidak menentu setiap harinya, telah disadari oleh Kepala Suku Dinas Sosial Kota Administrasi Jakarta Utara untuk membangun suatu posko pemantauan bagi para anak jalanan dan para Penyandang Masalah Kesejahtraan Sosial (PMKS) lainnya di Kota Administrasi Jakarta Utara. Posko untuk memantau anak jalanan dan Penyandang Masalah Kesejahteran Sosial (PMKS) di Kota Administrasi Jakarta Utara tersebut dibangun di enam titik di Kota Administrasi Jakarta Utara, yang meliputi:

1. Posko Mambo : Lampu Merah Enggano

2. Posko Kelapa Gading : Lampu Merah Summarecon

3. PoskoHailay Ancol : Lampu Merah Bintang Mas

4. Posko Penjaringan : Lampu Merah Gedong Panjang

5. Posko Plumpang : Pertigaan Plumpang Semper

6. Posko Coca Cola : Lampu Merah ITC Cempak Mas

Menurut peneliti, pembangunan posko pemantauan bagi para anak jalanan dan Penyandang Masalah Kesejahtraan Sosial (PMKS) di Kota Administrasi Jakarta Utara, merupakan suatu kebijakan yang tepat dari Kepala Suku Dinas Sosial Kota Administrasi Jakarta Utara. Posko pemantauan tersebut dapat dijadikan suatu tempat untuk mengumpulkan informasi yang dibutuhkan, seperti, mengenali berbagai macam aktifitas para anak jalanan di Kota Administrasi Jakarta Utara, mempererat hubungan kerjasama antara Suku Dinas Sosial Kota Administrasi Jakarta Utara dengan Lembaga Swadaya Masyarakat (LSM) yang menangani permasalahan anak jalanan di Kota Administrasi Jakarta Utara, dan menjadi tempat mengindentifikasi setiap permaslaahan anak jalanan guna menyeleksi pelayanan yang 
akan diberikan. Kebijakan Kepala Suku Dinas Sosial Kota Administrasi Jakarta Utara, menyangkut pembangunan posko pemantauan di 6 titik di Kota Administrasi Jakarta Utara peneliti lihat dari hasil observasi di lapangan telah memaksimalkan sesuai dengan semestinya, karena saat ini posko tersebut berisi petugas pemantau seperti yang telah ditentukan sebelumnya.

Hal penting selanjutnya dalam komunikasi yaitu konsistensi. Tentunya konsistensi diperlukan agar kebijakan yang diambil tidak simpang siur sehingga membingungkan pelaksana kebijakan, target group dan pihak-pihak yang berkepentingan. Perintah yang diberikan dalam pelaksanaan suatu komunikasi harus konsisten dan jelas, bila perintah yang diberikan sering berubah-ubah, maka dapat menimbulkan kebingungan bagi pelaksana di lapangan.

Proses komunikasi dalam pelaksanaan penanganan anak jalanan belum terlaksana dengan baik. Hal ini terjadi karena ada kondisi penyampaian informasi yang masih kurang efektif. Ada gap kemampuan pelaksana terhadap informasi kebijakan. Kondisi belum jelasnya komunikasi menyebabkan belum tercapainya perubahan yang diinginkan. Anak jalanan di Jakarta Utara masih banyak yang tidak mengetahui akan program tersebut.

\section{Sumber Daya}

Walaupun secara ideal isi kebijakan telah dikomunikasikan secara jelas dan konsisten, tetapi apabila implementor kekurangan sumber daya untuk melaksanakan, implementasi tidak akan berjalan efektif (Gumanti et al., 2020). Sumberdaya di sini bisa dimaknai sebagai hal-hal yang berkaitan dengan staff, information, authority, dan facilities (Edward III, 1980).

Pembahasan tentang staff diarahkan pada pembahasan kualitas pegawai-pegawai yang akan terlibat dalam pembuatan maupun pelaksanaan kebijakan. Membicarakan mengenai staff tidak hanya membicarakan soal angka saja karena keberhasilan implementasi kebijakan juga sangat dipengaruhi oleh kemampuan (kualitas) staff pelaksana. Oleh karenanya, dua aspek penting dalam menganalisa sumber daya dalam proses implementasi kebijakan publik, yaitu menganalisa size (ukuran) dan skills (kemampuan).

Tabel 2 Identitas Pegawai Menurut Tingkat Pendidikan

\begin{tabular}{|c|c|c|}
\hline No & Pendidikan & Jumlah \\
\hline 1. & SD & 1 Orang \\
\hline 2. & SMA & 18 Orang \\
\hline 3. & SMU & 1 Orang \\
\hline 4. & SMK & 1 Orang \\
\hline 5. & SI & 7 Orang \\
\hline 6. & S2 & 33 Orang \\
\hline \multicolumn{2}{|c|}{ Total } & \\
\hline
\end{tabular}

Sumber: Data diolah dari Suku Dinas Sosial Jakarta Utara (2017)

Berdasarkan tabel di atas diketahui bahwa pegawai terbanyak memiliki jenjang pendidikan SMA atau Sederajat dan Sarjana. Hal ini dapat mempengaruhi kualitas kinerja para pegawai dari sisi kemampuan professional dan keterampilan teknis para pegawai di Suku Dinas Sosial KotaAdministrasi Jakarta Utara. Sedangkan kualitas sumber daya manusia (aparatur) sangat diperlukan agar menajemen pemerintah dalam Suku Dinas Sosial Kota Administrasi Jakarta Utara dapat berlangsung secara efektif dan efesien, yang diperlukan tidak hanya jumlahnya yang cukup, tetapi juga kualitas para pegawai yang harus di ukur dengan melihat latar belakang pendidikan, keterampilan, pengalaman kerja, jenjang kepangkatan dan status kepegawaian. Dari 33 orang, efektif hanya ada 8 pegawai yang bertugas dalam penanganan Anak jalanan di Suku Dinas Sosial Kota Administrasi Jakarta Utara. Dari delapan orang tersebut, satu di antaranya adalah Kepala Seksi. Jadi jika Kepala 
Seksi tidak dihitung sebagai pelaksana lapang, maka anak jalanan dan PMKS se Jakarta Utara hanya akan ditangani oleh 7 orang saja (Diolah hasil wawancara dengan Kepala Seksi Rehabilitasi Sosial tanggal 25 April 2017).

Dengan pertimbangan kekurangan tenaga pelaksana, maka Kepala Seksi sekaligus bertindak sebagai pelaksana lapang dalam setiap operasi penjemputan anak jalanan dan penyerahan ke Panti Sosial. Kekurangan tenaga pula yang "memaksa" dilakukan kerja sama dengan Instansi Pemerintah seperti Kelurahan Kecamatan Sudin Tramtib Linmas Jakarta Utara. Tujuh orang tentu jumlah yang sangat tidak memadai untuk mengendalikan PMKS di enam kecamatan di wilayah Jakarta Utara. Apalagi Suku Dinas Sosial Kota Administrasi Jakarta Utara memiliki kepanjangan tangan (struktural) hingga ke tingkat kecamatan dan kelurahan.

Apabila kekurangan jumlah petugas lapangan bisa diatasi dengan meminta bantuan Sudin Tramtib Linmas Jakarta Utara serta Petugas P3S yang memiliki puluhan anggota P3S. Puluhan jumlah anggota Tramtib Linmas dan P3S Jakarta Utara belum termasuk anggota Tramtib Linmas yang ditempatkan di masing-masing kecamatan. Kekurangan tenaga juga dirasakan oleh panti sosial. Kurangnya tenaga pembina di panti sosial berjalan seiring dengan sedikitnya jumlah panti sosial untuk anak jalanan di Jakarta Utara, bahkan DKI Jakarta.

Selanjutnya, kekurangan tenaga pembinaan mengakibatkan pelayanan kepada anak jalanan dan PMKS pada umumnya tidak cukup memuaskan, baik dari segi kualitas maupun kuantitas. Dari sisi skills atau kemampuan pelaksana kebijakan, Suku Dinas Sosial Kota Administrasi Jakarta Utara tidak memiliki keluhan yang cukup substantif. Kemampuan penjemputan anak jalanan bukan kemampuan yang membutuhkan keahlian khusus. Artinya, penjemputan anak jalanan bisa dipelajari dengan cepat dan langsung dipraktikkan di jalanan. Keluhan mengenai skills justru muncul dari panti sosial.

Pelatihan yang diberikan panti sosial cenderung tidak memberikan alternatif alih profesi yang menarik bagi anak jalanan. Keterampilan dan pelatihan yang diberikan oleh petugas panti sosial terlalu usang untuk dijadikan alat mencari nafkah para mantan anak jalanan saat ini. Namun kurangnya skills ini bisa diatasi dengan bekerjasama dengan pihak lain dalam melakukan pelatihan. Kecenderungan yang mulai terlihat di beberapa instansi pemerintahan adalah melakukan kerja sama teknis dengan pihak lain untuk mengadakan kegiatan tertentu. Instansi pemerintah bertindak hanya sebagai penentu kegiatan dan penyandang dana. Dengan demikian, permasalahan skills petugas Panti Sosial bisa dialihkan menjadi masalah kecukupan anggaran.

Namun persoalannya dalam meningkatkan keterampilan petugas membutuhkan dana yang cukup besar; sementara rekrutmen petugas baru dalam jumlah cukup besar membutuhkan dana yang besar pula. Selain itu, direkrutnya petugas baru dengan ketrampilan tinggi memiliki konsekuensi pemberian gaji yang juga tinggi. Padahal standar gaji pegawai negeri masih terlalu sedikit, dan tidak sepadan, jika pegawai bersangkutan harus bekerja keras (penuh waktu) di panti sosial. Oleh karenanya alternatif langkah untuk mencapai perbaikan (kualitas) kemampuan petugas Panti Sosial adalah dengan mengharapkan skills upgrade terjadi secara alami melalui pengalaman dan rutinitas pekerjaan. Catatan dan kritik penting dari upgrading model ini yaitu, petugas menjadi orang terampil tapi tanpa membuka kemungkinan tercapainya inovasi baru. Kecil sekali kemungkinan muncul inovasi baru dalam pelayanan kepada anak jalanan jika petugas tidak diberi stimulus pengetahuan baru.

Sumberdaya authority membicarakan tentang hak dan kekuasaan untuk bertindak; kekuasaan membuat keputusan, memerintah, dan melimpahkan tanggung jawab kepada orang lain. Kebijakan penanganan anak jalanan memiliki struktur pelaksana bertingkat. Artinya terdapat beberapa jenjang instansi yang saling berhubungan, baik hubungan pertanggungjawaban secara vertikal maupun hubungan koordinasi secara horisontal. Kebijakan tidak akan bisa dilaksanakan bila tidak disertai pendelegasian kewenangan kepada pelaksana. 
Setiap tahap kegiatan penanganan anak jalanan yang dilakukan di Jakarta Utara telah disertai dengan kewenangan di antaranya yakni pada tahap perencanaan, kewenangan diberikan kepada Suku Dinas Sosial Kota Administrasi Jakarta Utaras dan Bappekodya Jakarta Utara. Sedangkan pada tahap pelaksanaan terdapat beberapa pihak yang diberi kewenangan berbeda yaitu Suku Dinas Sosial Kota Administrasi Jakarta Utara memiliki kewenangan hukum untuk menjemput anak jalanan, melakukan pendataan, kemudian mengirimkannya ke Panti Sosial. Suku Dinas Tramtib Linmas dan PSBIBD I dan PSBIBD II memiliki kewenangan untuk memberikan pelatihan, pembinaan dll. Pihak Kecamatan setempat memiliki kewenangan untuk menjemput anak jalanan yang berada di Wilayahnya. Sedangkan Polres, Polsek dan Satpol PP Jakarta Utara memiliki kewenangan untuk menangkap anak jalanan yang kemudian menyerahkannya kepada Suku Dinas Sosial Kota Administrasi Jakarta Utara. Pihak-pihak tersebut hanya memiliki kewenangan menangani jika terjadi campur tangan oknum militer atau polisi saat penjemputan anak jalanan berada di jalanan atau tempat-tempat umum.

Pada tahap pemantauan, kewenangan berada di tangan Suku Dinas Sosial Kota Administrasi Jakarta Utara, sedangkan tahap evaluasi, kewenangan berada pada Suku Dinas Sosial Kota Administrasi Jakarta Utara. Selanjutnya pada tahap pembinaan anak jalanan, kewenangan untuk melakukan pendataan, pemilahan, dan pembinaan terhadap anak jalanan berada pada Panti Sosial. Berikut ini merupakan uraian kegiatan monitoring dan evaluasi yang menjadi bagian dalam penanganan anak jalanan di Kota Administrasi Jakarta Utara tersebut:

1. Kunjungan terhadap shelter-shelter yang dijadikan sebagai tempat pemberdayaan anak jalanan

2. Kunjungan kepada keluarga dan masyarakat yang merupakan tempat tinggal anak jalanan

3. Fasilitasi pertemuan pada tingkat komunitas masyarakat

Uraian kegiatan monitoring dan evaluasi yang dilaksananakan oleh Kepala Suku Dinas Sosial Kota Administrasi Jakarta Utara, menurut peneliti sudah cukup tepat, karena monitoring dan evaluasi tersebut menjadi suatu jembatan bagi Kepala Suku Dinas Sosial Kota Administrasi Jakarta Utara untuk melihat sejauh mana tingkat pelaksanaan kegiatan pemberdayaan yang dilaksanakan oleh Panti Sosial dan rumah-rumah perlindungan anak. Dari uraian mengenai kewenangan yang dimiliki masing-masing pelaksana kebijakan

Selanjutnya sumberdaya yang dibahas adalah tentang fasilitas. Kelemahan paling mencolok dari pelaksanaan kebijakan penanganan Anak jalanan ini adalah jauhnya fasilitas dari memadai. Kendaraan operasional penjemputan yang dimiliki Suku Dinas Sosial Kota Administrasi Jakarta Utara hanyalah 2 mobil gerandong (seperti mobil tahanan) dan 1 mobil panter. Mobil tersebut merangkap juga sebagai mobil operasional harian Seksi Rehabilitasi Sosial, untuk sementara kebutuhan kendaraan pada saat penjemputan anak jalanan dari jalanan dan tempat-tempat umum masih bisa diatasi dengan bantuan mobil Tramtib Linmas dan mobil Suku Dinas Sosial Kota Administrasi Jakarta Utara.

Fasilitas Panti Sosial, terutama dari sisi kuantitas, ternyata jauh dari memadai. DKI Jakarta memiliki banyak Panti Sosial, namun di seluruh Wilayah DKI Jakarta hanya ada dua Panti Sosial yang diperuntukkan bagi penampungan sementara yaitu Panti Sosial Bina Bangun Daya 2 Cipayung Jakarta Timur dan Panti Sosial Bina Bangun Daya 1 Kedoya Jakarta Barat dan pembinaan anak jalanan, yaitu Panti Sosial Putra Utama Satu, Panti Sosial Putra Utama Dua, Panti Sosial Putra Utama Tigayang tersebar di Jakarta. Daya tampung ketiga panti sosial yang masing-masing berkisar pada angka 120 orang, tentu tak sepadan dengan ratusan, bahkan ribuan, anak jalanan yang ada di seluruh wilayah DKI Jakarta. 
Kurangnya fasilitas, terutama daya tampung panti sosial, membuat anak jalanan masih banyak dijumpai di jalanan. Perlu digarisbawahi bahwa penyebab banyaknya jumlah anak jalanan yang berada di jalanan, selain karena tidak semua anak jalanan bisa dijemput dan dikirim ke panti sosial yang daya tampungnya terbatas, adalah terjadinya migrasi anak jalanan yang sulit dibendung. Menurut pengakuan Suku Dinas Sosial Kota Administrasi Jakarta Utara menghentikan migrasi anak jalanan adalah hal yang paling tidak bisa dilakukan. Sepanjang yang diketahui, Pemkot Jakarta Utara tidak pernah mengeluarkan kebijakan untuk menahan/menghentikan arus migrasi anak jalanan. Perbatasan Jakarta terlalu luas untuk bisa diawasi setiap saat, sehingga anak jalanan tetap bisa melakukan perpindahan lintas batas secara sporadis.

Menurut pengakuan Suku Dinas Sosial Kota Administrasi Jakarta Utara menghentikan migrasi anak jalanan adalah hal yang paling tidak bisa dilakukan. Sepanjang yang diketahui, Pemkot Jakarta Utara tidak pernah mengeluarkan kebijakan untuk menahan/menghentikan arus migrasi anak jalanan. Perbatasan Jakarta terlalu luas untuk bisa diawasi setiap saat, sehingga anak jalanan tetap bisa melakukan perpindahan lintas batas secara sporadis.

\section{Disposisi}

Disposisi merupakan kemauan, keinginan dan kecenderungan para pelaku untuk melaksanakan kebijakan secara sungguh-sungguh sehingga apa yang menjadi tujuan kebijakan dapat diwujudkan (Edward III, 1980). Kecenderungan perilaku atau karakteristik ini berhubungan dengan respon para pelaksana kebijakan di dalam penanganan anak jalanan ini apakah mereka mendukung atau menolak kebijakan anak jalanan di Jakarta Utara.

Hasil riset menunjukkan bahwa para pelaksana kebijakan memiliki respon yang belum optimal dalam menjalankan kebijakan anak jalanan di Jakarta Utara. Dalam arti, secara normatif, para pelaksana telah menjalankan kebijakan tersebut, namun belum tampak sungguh-sungguh bila dilihat dari perspektif "tujuan kebijakan" karena faktor sumberdaya yang masih terbatas. Hal yang perlu dilihat dari disposisi adalah tentang karakteristik dari para pelaksana itu sendiri. Salah satu karakteristik birokrat tersebut adalah berkenaan dengan perilakunya. Ada beberapa perilaku yang relevan dibahas dalam konteks birokrat sebagai agensi pelaksana di antaranya kurangnya kesadaran bahwa hal yang diurus adalah manusia yang memiliki kompleksitas permasalahan dan kedua yaitu asumsi bahwa semua hal memiliki karakteristik yang sama. Kedua asumsi tersebut membuat birokrat melayani anak jalanan dengan cara yang kurang bijaksana.

\section{Struktur Birokrasi}

Hal substantif yanng perlu dibahas ketika membicarakan struktur birokrasi dalam pelaksanaan kebijakan publik adalah standard operating procedures (SOP) dan fragmentation (Edward III, 1980). Secara formil, Suku Dinas Sosial Kota Administrasi Jakarta Utara dan Panti Sosial telah memiliki SOP. Selama ini panduan yang dipergunakan oleh Suku Dinas Sosial Kota Administrasi Jakarta Utara dan Panti Sosial dalam menangani anak jalanan adalah Peraturan Menteri Sosial Republik Indonesia Nomor 30/Huk/2011 tentang Standar Nasional Pengasuhan Anak Untuk Lembaga Kesejahteraan Sosial Anak dengan beberapa penambahan dan pengurangan yang dikontekstualisasi dengan kondisi Jakarta Utara.

Cara penanganan anak jalanan bisa disesuaikan dengan kondisi riil yang dihadapi. Penjemputan anak jalanan yang berada di jalanan menjadi lebih fleksibel karena selalu terbuka kemungkinan untuk melajukan revisi aturan sewaktu-waktu. Fleksibilitas dalam menghadapi anak jalanan akan sulit dilakukan jika aturan/petunjuk teknis bersifat baku/formal/tertulis. Dalam pelaksanaannya, seperti telah dibahas sebelumnya, pelaksanaan kebijakan penanganan anak jalanan di Jakarta Utara diserahkan kepada aktor utama yaitu 
Suku Dinas Sosial Kota Administrasi Jakarta Utara dan Panti Sosial. Suku Dinas Sosial Kota Administrasi Jakarta Utara melakukan koordinasi dengan berbagai instansi lain untuk melakukan penjemputan terhadap anak jalanan yang berada di jalanan. Sementara Panti Sosial berperan sebagai pihak yang menampung anak jalanan dan melakukan pembinaan terhadapnya.

Terkait dengan fragmentation, pelaksanaan kebijakan penanganan anak jalanan di Jakarta Utara tidak mengalami fragmentasi. Di lapangan tidak terjadi fragmentasi koordinasi pelaksanaan kebijakan dan pemecahan pertanggungjawaban. Dalam pelaksanaan kebijakan tersebut tidak terjadi pemecahan koordinasi pelaksanaan kebijakan dan pemecahan pertanggungjawaban. Meskipun praktek di lapangan menunjukkan banyak pihak yang terlibat penanganan anak jalanan, namun puncak-puncak koordinasi dan pertanggungjawaban pelaksanaan tetap berada di tangan Suku Dinas Sosial Kota Administrasi Jakarta Utara dan Panti Sosial. Pihak-pihak selain Suku Dinas Sosial Kota Administrasi Jakarta Utara dan Panti Sosial yang terlibat dalam penanganan anak jalanan bertindak hanya atas permintaanSuku Dinas Sosial Kota Administrasi Jakarta Utara dan karena itu tidak memiliki kewenangan dan pertanggungjawaban khusus berkaitan dengan penanganan anak jalanan. Satu-satunya hal yang mengganggu dalam kaitannya dengan fragmentation, meskipun selama ini tidak menghambat pelayanan yang diberikan adalah koordinasi antarinstansi pascapenjemputan anak jalanan yang berada di jalanan.

Terdapat beberapa instansi yang memiliki kewenangan untuk menjemput anak jalanan, dengan berbagai alasan, dari jalanan dan menyerahkannya kepada panti sosial. Kemudian di panti sosial melakukan pendataan anak jalanan, asal wilayah penjemputan, dan instansi yang menjemputnya. beberapa instansi yang memiliki kewenangan menjemput anak jalanan yang berada di jalanan, kadang-kadang bersikap "arogan" dan tidak merasa perlu berkoordinasi dengan instansi lain, terutama Suku Dinas Sosial Kota Administrasi Jakarta Utara, alasan yang dikemukakan masing-masing instansi memang bisa diterima, masingmasing instansi tidak berkoordinasi dengan Suku Dinas Sosial Kota Administrasi Jakarta Utara karena memiliki tugas sendiri yang juga berlandasan hukum.

Walaupun banyak pihak yang terlibat penanganan anak jalanan, namun puncakpuncak koordinasi dan pertanggungjawaban pelaksanaan tetap berada di tangan Suku Dinas Sosial Kota Administrasi Jakarta Utara dan Panti Sosial. Sedangkan pihak-pihak selain Suku Dinas Sosial Kota Administrasi Jakarta Utara dan Panti Sosial yang terlibat dalam penanganan anak jalanan bertindak hanya atas permintaan Suku Dinas Sosial Kota Administrasi Utara dan karena itu tidak memiliki kewenangan dan pertanggungjawaban khusus berkaitan dengan penanganan anak jalanan. Adapun yang relatif menjadi kendala dalam kaitannya dengan fragmentasi adalah koordinasi antar instanasi pasca penjemputan anak jalanan. Hal ini terjadi karena pihak-pihak yang memiliki kewenangan dalam penjemputan memiliki argumentasi yang bisa diterima dan berlandaskan hukum tertentu. Contohnya Tramtib Linmas yang memiliki kewenangan untuk menjaga ketertiban di wilayah Jakarta Utara. Dalam praktiknya, Tramtib Linmas tidak perlu melakukan koordinasi dengan Suku Dinas Sosial Kota Administrasi Jakarta Utara.

\section{SIMPULAN}

Dari hasil studi sebelumnya, secara garis besar terdapat empat kesimpulan umum yang saling berkaitan, yaitu 1) Proses komunikasi dalam pelaksanaan penanganan anak jalanan belum terlaksana dengan baik. Hal ini terjadi karena ada kondisi penyampaian informasi yang masih kurang efektif. Ada gap kemampuan pelaksana terhadap informasi kebijakan. Selanjutnya, 2) Sumberdaya yang berkaitan dengan staff, information, authority, dan facilities juga masingmasing memiliki kekurangan sehingga kekurangan efektivitas dalam hal sumberdaya kebijakan. Kemudian, 3) Dalam konteks disposisi menunjukkan bahwa respon dari pemerintah Jakarta Utara belum optimal. Sedangkan dari 4) stuktur birokrasi, Suku Dinas 
Sosial Kota Administrasi Jakarta Utara dan Panti Sosial telah memiliki SOP tersendiri. Kemudian dalam stukrur birokrasi, pelaksanaan kebijakan penanganan anak jalanan di Jakarta Utara tidak mengalami fragmentasi. Di lapangan tidak terjadi fragmentasi koordinasi pelaksanaan kebijakan dan pemecahan pertanggungjawaban.

\section{DAFTAR PUSTAKA}

Astri, H. (2014). Kehidupan anak jalanan di Indonesia: faktor penyebab, tatanan hidup dan kerentanan berperilaku menyimpang. Jurnal Aspirasi, 5(2), 145-155.

Azmiyati, S. R. (2014). Gambaran Penggunaan Napza Pada Anak Jalanan Di Kota Semarang. Kemas: Jurnal Kesehatan Masyarakat, 9(2), 137-143. https://doi.org/https://doi.org/10.15294/kemas.v9i2.2841

Edward III, G. C. (1980). Implementing Public Policy. Congressional Quarterly Press.

Gumanti, L., Permana, I., \& Sutarjo, M. (2020). Implementasi Kebijakan Program Pembinaan Anak Jalanan di Dinas Sosial Kabupaten Cirebon. Jurnal Ilmiah Publika, 8(1), 9-15.

Khoirunnisa, Ratna, E., \& Irawati. (2020). Perlindungan Hukum Anak Terlantar Atas Hak Anak Mendapatkan Jaminan Kesehatan. Notarius, 13(1), 546-556.

Mambang, \& Wahyudi, H. (2016). Implementasi Kebijakan Gelandangan, Pengemis, Tuna Susila dan Anak Jalanan di Kota Palangka Raya Provinsi Kalimantan Tengah. Pencerah Publik, 3(2), 1-8.

Moleong, L. J. (2004). Metode Penelitian Kualitatif. PT. Remaja Rosdakarya.

Nazir, M. (2009). Metode Penelitian. Ghalia Indonesia.

Nurahmah, J. A. (2020). Implementasi Kebijakan Peraturan Daerah Nomor 14 Tahun 2017 Dilihat Dari Aspek Komunikasi Pada Dinas Lingkungan Hidup Kabupaten Tabalong. JAPB: Jurnal Administrasi Publik Dan Bisnis, 3(2), 1016-1030.

Suleman, S., Pakaya, R., \& Daud, Y. (2019). Pendataan Penyandang Masalah Kesejahteraan Sosial (Pmks) Berbasis Web. Jurnal Teknologi Informasi Indonesia, 4(1), 30-39.

Suyanto, B. (2013). Masalah Sosial Anak. Kencana Pranada Media Group.

Winarno, B. (2008). Kebijakan Publik Teori \& Proses. MedPress. 